\title{
Pathology and causes of death of stranded cetaceans in the Canary Islands (1999-2005)
}

\author{
Manuel Arbelo ${ }^{1, *}$, Antonio Espinosa de los Monteros ${ }^{1}$, Pedro Herráez ${ }^{1}$, \\ Marisa Andrada1, Eva Sierra1, Francisco Rodríguez ${ }^{1}$, Paul D. Jepson², \\ Antonio Fernández ${ }^{1}$
}

\author{
${ }^{1}$ Histology and Veterinary Pathology, Institute of Animal Health, Veterinary School, \\ University of Las Palmas de Gran Canaria, Canary Islands, Spain \\ ${ }^{2}$ Institute of Zoology, Zoological Society of London, Regents' Park, London NW1 4RY, UK
}

\begin{abstract}
Between 1999 and 2005, 233 stranded cetaceans (comprising 19 species) were reported in the waters of the Canary Islands. Of these, 138/233 (59.2\%) were subjected to a complete or partial standardized necropsy, including 4 Balaenopteridae, 9 Physeteridae, 8 Kogiidae, 27 Ziphiidae and 90 Delphinidae. Of these, 46/138 (33.3\%) cetaceans were diagnosed with anthropogenic pathological categories (i.e. the cause of death was anthropogenic). These included fishing interaction (bycatch) (19 individuals), 'atypical' mass stranding events linked to naval exercises (13), ship collisions (8) and other anthropogenic-related pathology (6). 'Natural' (i.e. non-anthropogenic) causes of death accounted for another 82/138 (59.4\%) cases, including infectious and non-infectious diseases (63), neonatal pathology (8), intra- and interspecific interactions (6) and mass strandings (5). The cause(s) of death could not be determined in 10/138 $(7.3 \%)$ necropsied animals. The most common causes of death were ship collisions in 6/9 (66.6\%) Physeteridae, 'atypical' mass stranding linked to naval exercises in 13/27 (48.1\%) Ziphiidae, and 'natural' infectious and non-infectious diseases in 55/90 (61.1\%) Delphinidae. Interaction with fishing activities was established as cause of death in 15/90 (16.7\%) Delphinidae. These data show that a range of anthropogenic and natural single and mass mortality events occur in multiple cetacean species stranded in the Canary Islands.
\end{abstract}

KEY WORDS: Dolphin $\cdot$ Whale $\cdot$ Strandings $\cdot$ Disease $\cdot$ Bycatch $\cdot$ Necropsy Resale or republication not permitted without written consent of the publisher

\section{INTRODUCTION}

The waters of the Canary Islands make up one of the richest and most diverse areas for cetaceans in the Northeast Atlantic, with 28 different species, 21 of the odontocete group and 7 of the mysticete group (Martín et al. 2009) having been reported. It is an area of extremely high natural value, in terms of numbers and diversity of cetaceans, due to its strategic position on the migratory path of many species and to its oceanographic characteristics (temperature, great depths near to the coast because of the lack of a continental shelf, abundant cephalopods and calm waters in the southwestern parts of the islands). This has given rise to the establishment of year-round resident populations of cetaceans, such as the common bottlenose dolphin Tursiops truncatus, short-finned pilot whale Globicephala macrorhynchus, Risso's dolphin Grampus griseus, sperm whale Physeter macrocephalus, Cuvier's beaked whale Ziphius cavirostris, Blainville's beaked whale Mesoplodon densirostris and Gervais' beaked whale Mesoplodon europaeus (V. Martín pers. comm.). The Canarian archipelago is the only place in Europe 
where it is possible to observe species such as shortfinned pilot whale, rough-toothed dolphin Steno bredanensis, Atlantic spotted dolphin Stenella frontalis and Bryde's whale Balaenoptera edeni all year round (Martín et al. 2009).

Of these 28 species, at least 26 have been found stranded on the coasts of the Canary Islands. There are historical references to cetacean stranding in the Canary Islands, but a more systematic study and scientific analysis has begun to take place only in the last 2 decades. The Canary Islands are densely populated and the anthropogenic impact on the marine environment includes effects of maritime traffic transporting cargo and people, the fishing industry and tourists observing cetaceans (whale watching). Marine life, including cetaceans, is affected by chemical pollution caused by dumping waste (urban, industrial and agricultural), and acoustic pollution caused by maritime traffic, hydrocarbon prospecting and extraction, and civil and military use of sonar. The examination of stranded cetaceans can be used to assess the impacts of these potentially detrimental activities. With this forensic aim, the present paper presents the first results of a systematic pathological study carried out on cetaceans stranded in the Canaries during a 6 yr period (1999 to 2005).

\section{MATERIALS AND METHODS}

Anatomic pathology was employed as the principal scientific-diagnostic method. A complete necropsy was carried out on the stranded animals using a standardized protocol (Kuiken \& García Hartmann 1991). Three age categories were used (newborn-calf, juvenile-subadult and adult) based on body length and gonadal appearance (Geraci \& Lounsbury 1993). The nutritional status of each animal was established morphologically with reference to anatomical parameters such as the presence of certain prominent bones, the dorso-axial muscular mass, and the absence or limited presence of fat, taking account of the species and the age of the animal. These led us to classify their nutritional status as good-moderate, moderate-poor, or emaciated. The state of decomposition was classified as very fresh, fresh, moderate autolysis, advanced autolysis or very advanced autolysis (Kuiken \& García-Hartmann 1991).

During the necropsies, most of the organs were sampled for histology. These samples were fixed in $10 \%$ buffered formalin, trimmed, processed routinely, embedded in paraffin, sectioned at $4 \mu \mathrm{m}$, and stained with hematoxylin and eosin (H\&E). Addition- ally, other histochemical techniques, including periodic acid-Schiff (PAS), Congo Red, Von Kossa, Oil Red O, osmium tetroxide post-fixation, Gram, Giemsa, phosphotungstic acid-haematoxylin stain (PTAH) and Masson's trichrome, were conducted when necessary (Prophet et al. 1992, García del Moral 1993, Bancroft \& Stevens 1996). Immunohistochemical tests were carried out using avidin-biotin-peroxidase complex (ABC) method described by Hsu et al. (1981) with modifications. The primary antibodies used in immunohistochemical tests were alpha-1-antitrypsin, CD3, fibrinogen, myoglobin, heat shock protein 70 and anti-Toxoplasma gondii.

From animals in a very fresh or fresh condition, or in a state of moderate autolysis, samples for microbiological studies were routinely taken whenever possible of, at least, skin with blubber, skeletal muscle, lung, liver, kidney, spleen and brain. The samples were stored at $-80^{\circ} \mathrm{C}$. Routine microbiological procedures were used to isolate and identify bacterial pathogens; these included streaking aseptically ground tissue suspensions and swab specimens over a variety of solid media including nutrient agar and blood agar followed by aerobic incubation at $37^{\circ} \mathrm{C}$. Microbiological identification was done by morphological and biochemical characterization of the isolates.

In some selected animals belonging to species considered to be resident in the Canary Islands waters (bottlenose dolphin, short-finned pilot whales and sperm whales), PCR techniques were used to diagnose the presence of herpesvirus and morbillivirus in selected samples. Molecular diagnosis of cetacean morbillivirus (CeMV) was carried out by reverse transcription-PCR (RT-PCR) amplification of a conserved 429-bp region in the morbillivirus phosphoprotein (P) gene (Barrett et al. 1993). Herpesvirus detection was performed by universal nested PCR as described previously (Van Devanter et al. 1996). The parasites found during the necropsy were classified (genus level) using established morphological characteristics (Howard et al. 1983).

\section{RESULTS}

A total of 233 cetaceans of 19 species were found stranded in the Canary Islands between October 1999 and September 2005. This paper presents morphopathological studies from 138 cetaceans from 17 different species (Table 1; individual case details in Table S1 in the supplement at www.int-res.com/ articles/suppl/d103p087_supp.xls). 


\section{Stranding epidemiology}

No significant biases/trends in distribution of sex were observed in any species. The average number of stranded animals during this period in the Canary Islands was $39 \mathrm{yr}^{-1}$ with the highest stranding rates in spring and early summer (April and May). From a total of 138 cetaceans included in this study, necropsy was carried out on 'very fresh or fresh' carcasses in $71 / 138$ (51.4\%) cases, on $28 / 138$ $(20.3 \%)$ animals with 'moderate autolysis' and on $39 / 138(28.3 \%)$ with 'advanced' or 'very advanced autolysis'.

Causes of death could be established in 128/138 of the cetaceans necropsied, and were classified as being of anthropological or natural (i.e. non-anthropological) origin (Table 1), as described in the following paragraphs.

\section{Anthropological pathological categories}

Interaction with fishing activities

This is defined as acute death of cetaceans after interaction with any type of fishing activity, whether by accidental capture (bycatch) or as a result of severe injuries caused by fishermen or fishing equipment (Kuiken et al. 1994). A total of 19 out of 138 $(13.8 \%)$ cetaceans belonging to 8 odontocete species were diagnosed within this pathological category: 6 Atlantic spotted dolphins, 4 bottlenose dolphins, 3 common dolphins, 2 striped dolphins, 1 Cuvier's beaked whale, 1 dwarf sperm whale, 1 Gervais' beaked whale and 1 pigmy sperm whale. These cases had traumatic lesions such as superficial cutaneous lesions caused by contact with fishing nets and ropes, wounds and fractures of the cranium and deep wounds made by fisheries instruments, sometimes penetrating the corporal cavities. The majority of cetaceans included in this pathological category were in a good body condition and showed an abundant stomach content which was fresh or only partially digested with the presence of chyle in the mesenteric lymphatic vessels as well as the in thoracic duct. We also found unspecific findings like edematous lungs and subpleural hemorrhages in some animals. We also consistently found some characteristic histopathological changes in these animals, including intracytoplasmastic hyaline globules in the hepatocytes and perivascular astrocyte ballonization in the brain.

Table 1. Cetacean strandings in the Canary Islands, 1999 to 2005. Number of cases by species in the different pathological categories. FBP: foreign body pathology; SC: ship collisions; IFA: interaction with fishing activities; MMUS: military maneuvers using sonar; MSP: mass stranding pathology; PSLNS: pathology associated with significant loss of nutrional status; PGNS: pathology with good nutritional status; NPP: neonatal-perinatal pathology; IITI: intra-/interspecific traumatic interactions; ND: not determined. ${ }^{*}$ Species most affected in each category

\begin{tabular}{|c|c|c|c|c|c|c|c|c|c|c|c|c|}
\hline \multirow{2}{*}{ Species } & \multirow[b]{2}{*}{ FBP } & \multicolumn{3}{|c|}{ Anthropogenic } & \multicolumn{5}{|c|}{ L Non-anthropogenic } & \multirow[t]{2}{*}{ ND } & \multirow{2}{*}{ Total } & \multirow{2}{*}{$\begin{array}{c}\% \text { of } \\
\text { all case }\end{array}$} \\
\hline & & $\mathrm{SC}$ & IFA & MMUS & MSP & PSLNS & PGNS & NPP & IITI & & & \\
\hline Balaenoptera physalus & 1 & 0 & 0 & 0 & 0 & 0 & 0 & 1 & 0 & 1 & 3 & 2.2 \\
\hline Delphinus delphis & 0 & 0 & 3 & 0 & 0 & $5^{*}$ & 2 & 0 & 0 & 0 & 10 & 7.2 \\
\hline Globicephala macrorhynchus & 0 & 0 & 0 & 0 & 0 & 3 & 1 & 0 & 1 & 1 & 6 & 4.3 \\
\hline Grampus griseus & 0 & 0 & 0 & 0 & 0 & 0 & 0 & 0 & 0 & 1 & 1 & 0.7 \\
\hline Kogia breviceps & 0 & 1 & 1 & 0 & 0 & 1 & 1 & 0 & 0 & 1 & 5 & 3.6 \\
\hline Kogia sima & 0 & 0 & 1 & 0 & 0 & 1 & 0 & 0 & 0 & 1 & 3 & 2.2 \\
\hline Lagenodelphis hosei & 0 & 0 & 0 & 0 & 0 & 1 & 0 & 0 & 0 & 1 & 2 & 1.4 \\
\hline Megaptera novaeangliae & 0 & 0 & 0 & 0 & 0 & 1 & 0 & 0 & 0 & 0 & 1 & 0.7 \\
\hline Mesoplodon densirostris & 0 & 0 & 0 & 1 & 0 & 2 & 0 & 2 & 0 & 0 & 4 & 2.9 \\
\hline Mesoplodon europaeus & 0 & 0 & 1 & 1 & 0 & 0 & 0 & 1 & 1 & 0 & 4 & 2.9 \\
\hline Physeter macrocephalus & 1 & $6^{*}$ & 0 & 0 & 0 & 0 & 0 & 0 & 1 & 1 & 9 & 6.5 \\
\hline Stenella coeruleoalba & 1 & 0 & 2 & 0 & 0 & 3 & $15^{*}$ & 2 & 2 & 0 & 25 & 18.1 \\
\hline Stenella frontalis & 2 & 0 & $6^{*}$ & 0 & 0 & $8^{*}$ & $8^{*}$ & 1 & 0 & 2 & 27 & 19.6 \\
\hline Stenella longirostris & 0 & 0 & 0 & 0 & 3 & 0 & 0 & 0 & 0 & 0 & 3 & 2.2 \\
\hline Steno bredanensis & 0 & 0 & 0 & 0 & 0 & 2 & 0 & 0 & 1 & 0 & 3 & 2.2 \\
\hline Tursiops truncatus & 0 & 0 & $4^{*}$ & 0 & 2 & $4^{*}$ & 3 & 0 & 0 & 0 & 13 & 9.4 \\
\hline Ziphius cavirostris & 1 & 1 & 1 & $11^{*}$ & 0 & 0 & 2 & 2 & 0 & 1 & 19 & 13.8 \\
\hline Total & 6 & 8 & 19 & 13 & 5 & 31 & 32 & 8 & 6 & 10 & 138 & \\
\hline$\%$ of all cases & 4.3 & 5.8 & 13.8 & 9.4 & 3.6 & 22.5 & 23.2 & 5.8 & 4.3 & 7.2 & & \\
\hline
\end{tabular}




\section{Foreign body pathology}

This is defined as the pathological disorder characterized by, in the majority of the cases, a poor body condition, with the presence of subacute and/or chronic organic lesions associated with physical etiological agents (e.g. fishing equipment, ropes, plastic) of anthropogenic origin. This category includes animals that had ingested foreign bodies and those who had become trapped or externally entangled. In this category we included 6/138 $(4.3 \%)$ cetaceans. Four animals of 3 different species presented foreign bodies within the stomach: 1 Cuvier's beaked whale, 2 Atlantic spotted dolphins and 1 striped dolphin; of these, 1 spotted dolphin was an adult and the remaining spotted dolphin, the striped dolphin and the Cuvier's beaked whale were juveniles or subadults. In all these cases, an abundant amount of plastic, derived from plastic bags, was observed in the stomach. In 3 of these individuals a large quantity of plastic was noted occupying and dilating the first stomach, together with gastric hemorrhages, whilst in the other case the plastic material was found better conserved, occupying part of the first stomach with no signs of gastric hemorrhages, but occluding the passage between the first and the second stomach.

In this category we also included 2 further cases associated with the presence of rubbish and dumping in the sea. In both cases the animal affected was an adult cetacean of a large species: a female fin whale and a male sperm whale. The fin whale showed a very poor body condition; a very long thick cable was wrapped around the tongue that reached the stomach, causing an ischemic glossitis and preventing feeding. The sperm whale also presented a poor body condition. It had an extremely resistant strand of plastic wrapped rostrally around the mandible body, with a massive quantity of plastic and nets forming a large ball to which numerous marine organisms were attached (algae, crustaceans, cirripeds). The animal also showed a chronic active fibrosis around a deep cut caused by this plastic material in the rostral area of the right mandible.

\section{Military manoeuvres using sonar}

This category refers to cases of 'atypical' mass stranding events (MSEs) in beaked whales that coincided with military naval manoeuvres with the use of sonar (Frantzis 1998, Jepson et al. 2003, Cox et al.
2006). In this category we included 13/138 (9.4\%) animals from 2 beaked whale atypical MSEs (11 Cuvier's, 1 Blainville's and 1 Gervais' beaked whales).

In the first stranding, 14 beaked whales were stranded close to the site of an international naval exercise ('Neo-Tapon 2002') held on 24 September 2002. Strandings began about $4 \mathrm{~h}$ after the onset of mid-frequency sonar activity; 8 Cuvier's, 1 Blainville's, and 1 Gervais' beaked whales were examined post mortem and studied histopathologically. No inflammatory or neoplastic processes were noted, and no pathogens were identified. Macroscopically, whales had severe, diffuse congestion and hemorrhage, especially around the acoustic jaw fat, ears, brain, and kidneys. Gas bubble-associated lesions and fat embolism were observed in the vessels and parenchyma of vital organs.

In the second stranding, in July 2004, 4 Cuvier's beaked whales stranded several days after an international naval exercise ('Majestic Eagle 2004') was conducted to the north of the Canary Islands. During the manoeuvres high intensity mid-frequency sonar was used. Three animals were fully studied pathologically. Abundant fresh non-digestive aliment was found in stomachs. In all cases, hemorrhages were found in several organs. Systemic fat embolism was diagnosed in 3 of the beaked whales.

Detailed pathological studies were published for 10 individuals from the 2002 event (Fernández et al. 2005) and 3 from the 2004 event (Fernández et al. 2012).

\section{Ship collisions}

This category refers to those cases of animals that suffered a severe trauma resulting in peracute or acute death associated with a collision with a vessel. Out of 138 cases, 8 (5.8\%) were diagnosed to have died from vessel collision. The majority of the affected animals (6/8) were sperm whales. The other 2 cases were 1 Cuvier's beaked whale and 1 pygmy sperm whale. All of them showed lesions of severe sharp trauma. Of these animals, $3 / 8$ showed the complete disseverance of part of the body with a linear cut, 4/8 showed a single linear cut that affected at least the skin, subcutaneous and deep muscular tissues and in 2 cases producing severe bone fractures and exposed cavities, and 1/8 showed 4 equally-spaced linear cuts (i.e. propeller injury) affecting skin, subcutaneous and deep muscular tissues. 


\section{Natural pathological categories}

\author{
Pathology associated with significant loss of \\ nutritional status
}

This was defined as pathological disorders characterized by moderate to poor nutritional status and associated with the presence of subacute and/or chronic organic lesions which were sufficiently severe to be considered ultimately responsible for the death and/or stranding of the animal. Such organic lesions can be caused by various agents, including biological agents (virus, bacteria, parasites, fungi and biotoxins). A total of 31/138 (22.5\%) animals were diagnosed within this pathological category, of which 30/31 (96.8\%) were odontocetes: Atlantic spotted dolphin (8 individuals), common dolphin (5), common bottlenose dolphin (4), striped dolphin (3), short-finned pilot whale (3), Blainville's beaked whale (2), rough-toothed dolphin (2), dwarf sperm whale (1), Fraser's dolphin (1) and pigmy sperm whale (1). The remaining animal was a mysticete, a humpback whale Megaptera novaeangliae. Main lesions were related to multiorganic parasitosis $(45.2 \%)$ affecting Atlantic spotted dolphin (4), common bottlenose dolphin (3), striped dolphin (3), common dolphin (2) and rough-toothed dolphin (2); and infectious pathology (32.2\%) affecting Atlantic spotted dolphin (3), striped dolphin (2), common bottlenose dolphin (1), common dolphin (1), dwarf sperm whale (1), Fraser's dolphin (1) and rough-toothed dolphin (1). In many cases, a combination of more than one type of pathology was seen in the same animal.

Variation in severity of multiorganic parasitic infestations was observed. Some of the lesions observed in this category, such as pyogranulomatous dermatitis, sacculitis, lymphadenitis and pneumonia, were associated with ciliate protozoa affecting 4 animals of different species (bottlenose, rough-toothed, spotted and striped dolphin). Pulmonary nematodes were the most frequently observed parasites (36.2\%). Within the infectious pathology cases, Corynebacterium sp. was isolated from bronchopneumonia and Staphylococcus aureus from pleuropneumonia in 2 different dolphins (striped dolphin and Fraser's dolphin respectively) that also presented verminous pneumonia. An isolation of Clostridium tertium and Salmonella sp. was associated in 2 stranded cetaceans (dwarf sperm whale and common dolphin) with loss of nutritional status and enterotoxemic or enteric/septic pathology respectively.

Eight out of $31(25.8 \%)$ of the stranded cetaceans were considered to be old animals based on their bio- logical, anatomical and histological characteristics. These consisted of Atlantic spotted dolphin (4), Blainvilles's beaked whale (2), common dolphin (1) and striped dolphin (1). The main histological findings associated with age found in these animals were thyroid cysts, nodular corticoadrenal hyperplasia, lymphoplasmocytic adrenalitis, hyalinosis and amyloidosis in different organs (mainly lymph nodes and choroid plexus) and neuronal lipofuscinosis. Other age-related changes were siderofibrotic nodules in spleen and calcifications of bronchial cartilages.

\section{Pathology associated with good nutritional status}

This category comprises those stranded cetaceans with a good nutritive condition without external signs of having been injured by anthropogenic activity. These animals showed severe acute or peracute organic lesions, generally involving vital organs resulting in a rapid death. In this category, 32/138 $(23.2 \%)$ stranded cetaceans were included, consisting of striped dolphin (15), Atlantic spotted dolphin (8), common bottlenose dolphin (3), common dolphin (2), Cuvier's beaked whale (2), short-finned pilot whale (1) and pigmy sperm whale (1). The principal etiological diagnostic corresponded to infectious pathology (53.1\%), parasitic pathology (18.7\%) and other pathologies $(15.6 \%)$. The infectious pathologies included septicemic processes affecting striped dolphin (4), Atlantic spotted dolphin (2) and Cuvier's beaked whale (1); and nonpurulent meningoencephalitis consistent with a viral or bacterial infection affecting striped dolphin (7) and common bottlenose dolphin (2). In this category we included 7/32 cetaceans that presented acute septic processes. In 4 striped dolphins, pleuritis and/or pneumonia were observed as the primary source of an acute septic process and there was 1 case, in another male adult striped dolphin, of systemic and fatal pyogranulomatosis caused by Nocardia farcinica.

The number of striped dolphins, i.e. 11/138 (8.0\%), with mild to severe nonpurulent meningitis, encephalitis or meningoencephalitis was higher than for all other species in this study. Two bottlenose dolphins and one rough-toothed dolphin included in this category showed meningitis or meningoencephalitis associated with the presence of parasites (Nasitrema sp.) within the pterygoid sinuses. We also observed encephalitis caused by Toxoplasma gondii in 2 Atlantic spotted dolphins. Three cases of post-renal urinary obstruction were observed: 2 of an intralumi- 
nal obstructive infestation of Crassicauda sp. occluding the ureters, and 1 case where the ureters were closed by the external pressure associated to a large abscess.

Finally, in this category, we also included a primary lymphoblastic T-cell lymphoma located in the brain thalamus of a common dolphin and 2 B-cell multicentric lymphoblastic lymphoma detected in an Atlantic spotted dolphin and a bottlenose dolphin, respectively. A gastric papilloma in a bottlenose dolphin and a cutaneous papilloma in a striped dolphin represented the only other tumors diagnosed during our study $(3.6 \%)$.

\section{Neonatal or perinatal pathology}

This category refers to those cases of neonatal cetaceans whose morphological and etiological characteristics are related to possible problems in gestation, birth, nursing or behavior. Eight out of 138 $(5.8 \%)$ animals were included in this group: 2 Cuvier's beaked whales, 1 Blainville's beaked whale, 1 Gervais' beaked whale, 2 striped dolphins, 1 Atlantic spotted dolphin, and 1 fin whale. Pulmonary fetal atelectasis, presence of intrapulmonary meconium detected microscopically and general diffuse congestive-hemorrhagic lesions were the main findings in these animals.

Intra- and interspecific traumatic interactions

This category refers to cases of cetaceans affected by traumatic interactions with individuals of the same species (intraspecific), or with other species of cetaceans or other marine animals (interspecific). In this pathological category we included 6/138 (4.3\%) animals belonging to 5 species: 2 striped dolphins, 1 rough-toothed dolphin, 1 pilot whale, 1 sperm whale and 1 Gervais' beaked whale. Lesions observed varied from superficial parallel skin marks due to intraspecific interaction to severe traumatic lesions represented by fractured ribs and subcutaneous and pulmonary hemorrhages.

In the cases of the 2 striped dolphins the lesions observed were consistent with fatal interaction with one or more bottlenose dolphins based on the presence of the characteristic tooth-rake marks together with other traumatic lesions. Similar lesions were observed in the rough-toothed dolphin but in this case the tooth-rake marks could be attributed either to bottlenose dolphins or rough-toothed dolphins.
With respect to the other animals (pilot whale, Gervais' beaked whale and sperm whale), the lesions observed were characteristic of a blunt trauma caused by multiple traumatic impacts from other animals of unknown species.

Mass stranding pathology

This category refers to those cases of 'typical' or 'classical' MSEs defined as 2 or more cetaceans (excluding parent-calf pairs) coming ashore alive at the same time and place (Geraci \& Lounsbury 1993). Five out of $138(3.6 \%)$ animals were included in this category. During the period of time that comprises our study we attended 2 dolphin MSEs. The first one involved more than a dozen bottlenose dolphins; 3 of these animals died, of which 2 were necropsied. The second event involved 5 spinner dolphins; of these, 3 died ( 2 sub-adults and 1 adult), all of which were necropsied.

The first MSE occurred on a rocky beach during a night with bad weather and sea conditions, which is why data of the total number of stranded animals (between 12 and 15), sex and ages are incomplete or vague. Several animals were successfully returned to the sea; 4 adult females stranded repeatedly after several attempts to return them to the sea and were transported to the island wild animal rescue center where they stayed for $24 \mathrm{~h}$ before being transported by boat to open oceanic waters and released. Of the 3 dead animals, 1 of the carcasses could not be recovered and the other 2, corresponding to an adult female and a male calf, were necropsied. The lesions observed in both animals were mainly related to the 'stress stranding syndrome' and the adult female showed a diffuse verminous bronchopneumonia and a severe infestation of the pterygoid sinuses with Nasitrema sp., but no inflammatory associated brain lesions were observed.

The second MSE involved 5 spinner dolphins, being the first and only observation of this species in the Canary Islands, either stranded or alive at sea. Two of the animals were identified as juveniles based on body length and were successfully returned back to the sea. The other 3 animals consisted of 2 juvenile males that died during the stranding and 1 adult male that was transported to a rehabilitation centre where it was euthanized a few hours later (all 3 were necropsied). The most relevant lesions observed corresponded to the adult male, which showed a very poor nutritional status and a severe generalized proliferative dermatitis. 


\section{DISCUSSION}

\section{Stranding epidemiology}

Given the limited number of individuals and species examined by pathological studies with similar objectives carried out in different parts of the world (Stroud \& Roffe 1979, Cowan et al. 1986, Baker 1992, Di Guardo et al. 1995, Kirkwood et al. 1997, Parsons \& Jefferson 2000, Bogomolni et al. 2010), our results represent an important contribution to scientific data on number of different species, in particular Atlantic spotted dolphins and members of the Ziphiidae family (Cuvier's, Blainville's and Gervais' beaked whales). The highest number of strandings generally occurred in spring and early summer due to the greater presence of multiple cetacean species during those months, including common dolphins, striped dolphins and Atlantic spotted dolphins (Martín et al. 2009).

\section{Anthropological pathological categories}

Anatomic pathology was the principal scientific-diagnostic method employed, based on the detection of lesions (morphological diagnostic), and their association with likely etiologies, identified with or without complementary analysis (etiological diagnostic, Table 2). The study identified a range of pathological categories of anthropogenic origin.

\section{Interaction with fishing activities}

There is not much detailed information in the scientific literature about the pathology and pathogenesis of bycatch of dolphins. The impact of this activity on different species of cetaceans has increased in recent decades, and it is currently one of the main causes of dolphin mortality (Spencer et al. 2000).

The overall number of our cases included in this category represents similar percentages to those reported in Wales (17\%) (Baker 1996) and in the
United Kingdom as a whole (12\%) (Kuiken et al. 1994), but they are markedly lower than those described in England and Wales for some individual species (Kirkwood et al. 1997). On the other hand, this study reports on a greater diversity of species, which reflects the biodiversity of cetaceans that inhabit and strand in the Canary Islands. It is also obvious that these strandings do not represent the actual numbers of animals killed by fishing activities in Canary Islands waters, as we assume that this must be much higher (Tregenza 1996, Tregenza \& Collet 1998, Spencer et al. 2000).

Various authors indicate that harbor porpoises, common dolphins, bottlenose dolphins and other dolphins

Table 2. Cetacean strandings in the Canary Islands, 1999 to 2005. Number of cases of etiological diagnosis in the different pathological categories

\begin{tabular}{|c|c|c|}
\hline Pathological category & Etiologic diagnosis & No \\
\hline \multicolumn{3}{|l|}{ Anthropogenic origin } \\
\hline \multirow[t]{2}{*}{ Foreign body pathology } & Foreign body entanglement & 2 \\
\hline & Foreign body ingestion & 4 \\
\hline Collisions with vessels & Keel or propeller sharp trauma & 8 \\
\hline \multirow{3}{*}{$\begin{array}{l}\text { Interaction with } \\
\text { fishing activities }\end{array}$} & Blunt trauma & 2 \\
\hline & Bycatch & 8 \\
\hline & Fishing tool sharp trauma & 9 \\
\hline \multirow[t]{2}{*}{$\begin{array}{l}\text { Military manoeuvres } \\
\text { with the use of sonar }\end{array}$} & $\begin{array}{l}\text { Gas-fat embolic pathology consistent } \\
\text { with severe decompression process }\end{array}$ & 10 \\
\hline & $\begin{array}{l}\text { Fat embolic pathology consistent with } \\
\text { severe decompression process }\end{array}$ & 3 \\
\hline \multicolumn{3}{|l|}{ Natural origin } \\
\hline \multirow{3}{*}{ Mass stranding } & Social cohesion & 2 \\
\hline & Not determined & 2 \\
\hline & $\begin{array}{l}\text { Severe cachexia. Severe generalized } \\
\text { dermatitis }\end{array}$ & 1 \\
\hline \multirow{10}{*}{$\begin{array}{l}\text { Pathology associated } \\
\text { with significant loss } \\
\text { of nutritional status }\end{array}$} & Parasitic disease & 16 \\
\hline & Senile changes & 8 \\
\hline & Bacterial disease & 7 \\
\hline & Unknown origin septicemia & 6 \\
\hline & Mother-calf separation & 5 \\
\hline & Unknown origin meningoencephalitis & 2 \\
\hline & Chronic kidney disease & 1 \\
\hline & Congestive heart failure & 1 \\
\hline & Neoplasia & 1 \\
\hline & Viral disease & 1 \\
\hline \multirow{10}{*}{$\begin{array}{l}\text { Pathology associated } \\
\text { with good nutrional } \\
\text { status }\end{array}$} & Unknown origin meningoencephalitis & 9 \\
\hline & Unknown origin septicemia & 7 \\
\hline & Bacterial disease & 6 \\
\hline & Parasitic disease & 6 \\
\hline & Senile changes & 6 \\
\hline & Congestive heart failure & 2 \\
\hline & Neoplasia & 2 \\
\hline & Chronic kidney disease & 1 \\
\hline & Spontaneous pleural rupture & 1 \\
\hline & Viral disease & 1 \\
\hline $\begin{array}{l}\text { Neonatal or perinatal } \\
\text { pathology }\end{array}$ & Fetal distress. Neonatal weakness & 8 \\
\hline $\begin{array}{l}\text { Traumatic intra- and } \\
\text { interspecific interaction }\end{array}$ & $\begin{array}{l}\text { Blunt trauma, bite scars and/or } \\
\text { tooth-rake marks }\end{array}$ & 6 \\
\hline
\end{tabular}


are frequently involved in interaction with fishing activities (Baker 1992, 1996, Baker \& Martin 1992, Kuiken et al. 1994, Kirkwood et al. 1997, Cox et al. 1998). In our study, the majority of affected animals (15/19) belong to 4 different species of the Delphinidae family (Atlantic spotted dolphin, bottlenose dolphin, striped dolphin and common dolphin). The presence of other species such as pigmy sperm whale, dwarf sperm whale, Gervais and Cuvier's beaked whales should also be highlighted, as fisheries interactions have rarely or never been diagnosed as the cause of mortality of these species in this part of the Atlantic.

The diagnosis of bycatch/interaction with fisheries is made using a series of criteria, such as the exclusion of all other possible causes (Kuiken 1996). Signs of diagnostic value include the presence of associated traumatic lesions that normally occur a short time before death. In our case, we observed a range of characteristic traumatic lesions, including superficial cutaneous lesions caused by contact with fishing nets and ropes, wounds and fractures of the cranium and deep wounds made by fisheries instruments, sometimes penetrating the corporal cavities.

The majority of animals included within this pathological category were found in a good body condition. Our study found evidence that the majority of cetaceans included in this pathological category showed abundant stomach content, made up of fresh or only partially digested food. Another sign was the presence of chyle in the mesenteric lymphatic vessels and the thoracic duct. This condition was almost always present in the cases included in this pathological category.

Non-specific conditions such as edematous lungs were also found in the majority of cases in this pathological category, varying only in the severity of the alveolar edema. Subpleural hemorrhages (Paltauf's spots), described as a frequent lesion in human drowning cases (Lunetta \& Modell 2005), were detected in some animals in our study.

Other related histological changes included some histological features associated with stress and acute hemodynamic changes, such as the presence of hyaline intracytoplasmatic vacuoles in hepatocytes. These globuli contained acute phase glycoproteins (fibrinogen and alpha-1-antitrypsin), which have also been observed in cetaceans stranded alive not related to fishing activities (Jaber et al. 2004).

Other changes coming from hemodynamic alterations were shown in the hematoencephalic areas in the brain. When the animal is in a state of shock or stress it produces an extravasation of plasma to the Virchow-Robbins space. This plasma is absorbed by astrocytes, modifying their star-shaped morphology to a globular one, a process termed 'perivascular astrocytic balloonization'. This non-specific lesion was also identified in our study in other situations not associated to fishing activities, mainly in active strandings.

\section{Foreign body pathology}

In spite of regulations and warning notices, more than 6 million tonnes of rubbish are thrown into the ocean every year (O'Hara et al. 1994). The majority is plastic and more than $90 \%$ comes from coastal dumping (Faris \& Hart 1994). Globally, at least a total of 267 species of marine life have been affected by entanglement and the ingestion of waste, including 26 species of marine mammals (23 cetaceans) (23\%) (Laist 1996). In our study, the cause of death or the stranding was directly related to the fatal ingestion or external entrapment of the animals with foreign bodies in 6/138 $(4.3 \%)$ of the studied cases, affecting 5 different species, a low but not negligible percentage.

\section{Military manoeuvres with the use of sonar}

The parameters that define this category are established by Fernández et al. (2005, 2012), based on analysis of the cases reported in this study. This pathological category presents lesions in cetaceans that are similar to those of acute decompression-like disease in humans and laboratory animals. There is evidence of gas bubbles, presumably nitrogen, and of vascular and tissue changes consistent with those caused by gas bubble injuries and fat emboli.

These atypical MSEs of beaked whales were temporally and spatially coincident with naval exercises employing mid-frequency sonar. The animals were presumed to have died or to have been stranded with a decompression sickness-like disease and died shortly after with severe cardiovascular failure brought on by 'stranding stress syndrome'. Following publication of the pathological findings from the 2002 MSE, the Spanish Government introduced a ban on anti-submarine active sonars within a $50 \mathrm{~km}$ radius around the Canary Islands. Since the ban on active sonars, no new atypical beaked whale MSEs have occurred (Fernández et al. 2012).

\section{Ship collisions}

Ship collisions reported in the Canarian archipelago affect a variety of different species (André et al. 1997, 
Carrillo \& Tejedor 2006, De Stephanis \& Urquiola 2006). Maritime traffic in Canary Islands waters has increased significantly in recent decades with the introduction of high-speed fast-ferries. This has contributed to a higher number of collisions with large cetaceans, which are particularly at risk as some of the main maritime transportation routes traverse areas where small and large cetaceans are located.

Laist et al. (2001) point out that the majority of animals affected by collisions with vessels are calves or juveniles, which could be related to the greater proportion of time that calves spend at the surface compared with adults, who spend the majority of their time feeding at depth, and/or to an acquired ability of adults to avoid collisions. In our cases 3 of the 8 animals that died in ship collisions were calves and the other 5 were juveniles or subadults.

All the species involved in collisions in the Canaries (apart from 1 fin whale) belonged to the deep-diving group. These species require a prolonged period of recuperation at the surface after one or more apneas.

With the types of vessel involved, with the exception of 1 case involving a low-speed heavy ship with a large propeller, the lesions found were consistent with severe sharp trauma produced by large highspeed vessels, with keels producing one deadly deep cut; in some cases the animal's body was completely sectioned.

The Canary Islands stranding network has reported 11 further possible or probable cases of cetacean mortality due to ship collisions, additional to those considered in the present study (Carrillo \& Ritter 2010). As these were animals on which a necropsy could not be completely performed, due to the advanced state of autolysis and/or the impossibility of access to the animal, we were unable to determine whether the collisions were ante or post mortem. Therefore these animals were not included in this study.

\section{Natural pathological categories}

Natural pathological categories included a variety of causes of death of non-anthropogenic origin.

\section{Pathology associated with significant loss of nutritional status}

Many cetaceans strand with clear evidence of emaciation associated with lesions and disease (Moore et al. 2003). However, it is difficult to establish whether this condition results from a single or multiple etio- pathogenic mechanisms. It is also difficult to define which of the etiologies identified during the necropsy or by complementary analysis are the primary or secondary deleterious impact or which of them play the most defining role in the consumptive process and/or death of the animal.

The role of parasites as a cause of stranding and death has been widely discussed in scientific literature (Howard et al. 1983, Raga et al. 1997, Dailey 2001). In our study, we were able to verify its high prevalence, but its etiopathogenic value is clearly conditional on the functional importance of the affected organ.

A state of immunodepression associated with viral infections (e.g. morbillivirus) seems to be one of the reasons why ciliate protozoa (Kyaroikeus cetarius) thrive in the skin of cetaceans (Schulman \& Lipscomb 1999). This could explain some of the pathologies in our study, in which together with infestation of skin, air sacs, lymph nodes and lungs by protozoa ciliates, lesions compatible with a viral infection and/or immunosuppression, such as non suppurative encephalitis and lymphoid depletion, were detected.

Trematodes of the genus Nasitrema sp. can be a significant cause of stranding in various odontocete species, producing a neuropathy in the eighth cranial nerve (Morimitsu et al. 1986, 1992), encephalitis (O'Shea et al. 1991) and cerebral necrosis (Dailey \& Walker 1978, Lewis \& Berry 1988). A previous study of cetacean stranding in the Canaries (Degollada et al. 2002) described the occurrence and lesions caused by this trematode in the stranded odontocetes, ranging from a moderate sinusitis to severe meningoencephalitis.

The parasitic diseases that affect the liver and pancreas are most frequently associated with trematodes of the genus Campula (Woodard et al. 1969, Zam et al. 1971, Dailey \& Stroud 1978). This was verified by this study, where we observed the presence of these trematodes in 8 animals of 4 species (4 striped dolphins, 2 Atlantic spotted dolphins, 1 common dolphin and 1 rough-toothed dolphin). These parasites cause severe chronic cholangitis and pancreatic ductitis, and their eggs produce acute granulomatous hepatitis and pancreatitis (Dailey \& Stroud 1978), which we also observed in our study. An active chronic hepatitis was frequently seen in many cases, likely related to a chronic immunoreaction to parasites in the liver (Jaber et al. 2004).

The lesions and symptoms of pulmonary nematode infestations vary according to host and parasite, as well as the severity of infestation. The pulmonary parasitic lesions we observed were very similar to cetacean verminous pneumonia reported by Johnston 
\& Ridgway (1969), Woodard et al. (1969), and Migaki et al. (1971). The bacterial pulmonary infections are considered as secondary infection in immunodepressed or weak individuals (Jepson et al. 1999).

Senescence is a limiting factor in the development of the basic functions of animals, both from a biological and physiological point of view (Reynolds \& Rommel 1999, Dierauf \& Gulland 2001). Therefore, it is logical to assume that a progressive deterioration in the vital activities of these animals occurs, which could in part explain a progressive undernourishment. We observed that many animals included in this category were affected by lesions and histological changes associated with aging, as found in cetaceans by other authors (Cowan 1995, Lair et al. 1997, Cowan \& Tajima 2006).

\section{Pathology associated with good nutritional status}

This pathological category, representing animals with good body condition and acute or peracute lesions, was the second most common category among the animals necropsied. The most common pathologies presented were lesions of infectious etiology, especially septicemia and meningoencephalitis. To our knowledge, the case of the systemic pyogranulomatosis caused by Nocardia farcinica represents the first report of these bacteria in a striped dolphin.

The presence of leptomeningitis or nonpurulent meningoencephalitis was observed predominantly in striped dolphins and was compatible with a chronic infection by morbillivirus or with a Brucella sp. infection. In the literature, morbillivirus infections have been described as presenting both an acute and devastating course and a chronic or residual form. An example of the latter occurred after the epizooty of 1990 on the Spanish Mediterranean coast, and was characterized by chronic lesions in the nervous system of striped dolphins (Domingo et al. 1995). Nevertheless, cases of striped dolphins with chronic nonsuppurative meningoencephalitis associated with the presence of Brucella sp. have also been described (González et al. 2002). In our study it was not possible to check the presence of morbillivirus or Brucella sp. by means of immunohistochemistry, bacterial cultures or PCR in these striped dolphins, precluding a definitive etiological diagnosis.

We observed the presence of trematodes (Nasitrema sp.) in the nasal sacs and the pterygoid sinuses in 15 animals of 6 species ( 5 bottlenose dolphins, 4 Atlantic spotted dolphins, 2 spinner dolphins, 2 striped dolphins, 1 common dolphin and 1 rough-toothed dolphin). An interesting finding was the association of nonpurulent meningitis or meningoencephalitis and parasitic sinusitis caused by Nasitrema sp., especially in cetaceans that stranded alive. We definitively observed this association in 2 bottlenose dolphins and 1 rough-toothed dolphin. These parasites have been previously described in odontocete cetaceans causing neurological lesions and disorientation leading to massive strandings (Morimitsu et al. 1986, 1992).

Toxoplasma gondii has been detected locally in brain causing encephalitis or systemically in various species of cetaceans (Cruickshank et al. 1990, Inskeep et al. 1990, Migaki et al. 1990, Di Guardo et al. 1995, Mikaelian et al. 2000, Jardine \& Dubey 2002, Resendes et al. 2002, Bowater et al. 2003, Dubey et al. 2003). However to our knowledge this study contains the first report of toxoplasmosis in Atlantic spotted dolphins.

A brain T-cell lymphoma in the thalamus of a common dolphin reported here also represents the first case, to our best knowledge, of a primary lymphoma in the central nervous system in cetaceans. The low prevalence of neoplasia found in this study is similar to other studies carried out in stranded cetaceans with the exception of the St. Lawrence beluga whale population (Newman \& Smith 2006).

\section{Neonatal or perinatal pathology}

In these cases, we considered the presence of meconium in the lungs and subcutaneous hemorrhages as indicators of fetal suffering (Caswell \& Williams 2007). We also suggest that maternal separation and nursing difficulties after calving may be an important predisposing factor of neonatal death.

Traumatic lesions caused by intraspecific interaction can also affect neonates (Dunn et al. 2002). We observed intraspecific traumatic lesions in newborn animals, 2 striped dolphins and 1 Atlantic spotted dolphin, but in both cases these could have been caused by the mother or by other members of the group trying to keep the animal moving or to make it surface.

Intra- and interspecific traumatic interaction

Superficial parallel skin lesions due to intraspecific interaction are common in odontocete cetaceans (Greenwood at el. 1974). This type of lesions was observed in the majority of species included in this study. Severe traumatic lesions have also been described, characterized by fractured ribs and subcuta- 
neous, muscular and pulmonary hemorrhages, in harbor porpoises Phocoena phocoena (Ross \& Wilson 1996, Jepson \& Baker 1998) and bottlenose dolphin calves killed by adult bottlenose dolphins (Patterson et al. 1998, Dunn et al. 2002).

It is suspected that these types of lesions also occur as a result of interactions with other species. Lesions observed in 2 striped dolphins in this study were most probably associated with interactions with bottlenose dolphins, inferred from the characteristic distance between the tooth-rake marks. Lesions in a rough-toothed dolphin could have been caused either by animals of the same species or by bottlenose dolphins. Individuals of 3 other species (Gervais' beaked whale, short-finned pilot whale and sperm whale) were diagnosed as affected by blunt trauma due to intra- or interspecific interaction, but the causal species could not be identified due to the non-specificity of the lesions. in fact, in these cases, other possible causes such as vessel collisions could not be definitively ruled out.

\section{Mass stranding pathology}

Why cetaceans mass strand is still a mystery. Many different theories exist (Geraci \& Lounsbury 1993) and different causes are often attributed to individual cases of mass stranding (Bogomolni et al. 2010). With regard to bottlenose dolphin MSE reported in this study, the adult female necropsied showed a variety of organic lesions but, of these, only a parasitic infection by Nasitrema sp. has previously been identified as a cause of stranding. This parasite can affect the auditory nerves (Morimitsu et al. 1986, 1992) and even penetrates and damages the brain; however such lesions were not detected in this animal. The stranded calf died due to cardiovascular failure associated with stranding stress syndrome, lesions which were also detected in the adult animal. Therefore, the cause of the stranding was not identified.

The circumstances surrounding the spinner dolphin mass stranding case were exceptional, since this is the only report from the Canary Islands of a species usually confined to more tropical waters (Perrin 1987). Moreover, the oceanographic conditions associated with the event were unusual: the water temperature was significantly higher compared with the average for this area and season, and an atypical cyanobacteria bloom was associated with this increase of the sea temperature.

The only adult animal stranded showed signs of a severe consumptive disease associated with a general- ized chronic dermatitis. This could have been the immediate cause of the stranding, with the other subadult dolphins staying close to the sick animal, in accordance with the high level of social cohesion known to be characteristic of this species (Perrin 1987).

\section{CONCLUSIONS}

The use of anatomic pathology to determine pathologies and cause(s) of death in 138/233 (59.2\%) of the cetaceans stranded in the Canary Islands between October 1999 and September 2005 allowed us to classify $128 / 233(54.9 \%$ ) of the cetaceans studied into one of the anthropogenic or non-anthropogenic pathological categories. The most important anthropogenic causes of death included interactions with fishing gear (including bycatch), foreign body pathology, atypical strandings of beaked whales associated with military manoeuvres and sonar, and collisions with vessels (particularly in sperm whales) (Table 1). The most important natural (non-anthropogenic) causes of death included loss of nutritional status (starvation) and a range of infectious and noninfectious diseases. The use of these pathological categories enabled effective analysis of the possible causes of death of the stranded cetaceans in the Canary Islands. The results of the study will provide important inputs for cetacean conservation and management and marine conservation policy in the Canary Islands.

Acknowledgements. We thank the Dirección General del Medio Natural del Gobierno de Canarias, Ministerio de Ciencia e Innovación (Project CGL 2009-12663), Ministerio de Medio Ambiente, Rural y Marino and Agencia Canaria de Investigación (Project C2008-01000288) for economically supporting the present work. We thank Mariña Méndez and Ana Godinho for assisting in the necropsies and Pedro Castro, Ana María Afonso and Agueda Sosa for technical assistance.

\section{LITERATURE CITED}

André M, Terada M, Watanabe Y (1997) Sperm whale (Physeter macrocephalus) behavioral response after the playback of artificial sound. Rep Int Whaling Comm 47: 499-504

Baker JR (1992) Causes of mortality and parasites and incidental lesions in dolphins and whales from British waters. Vet Rec 130:569-572

Baker JR (1996) By-catches of cetaceans around the coast of Wales. In: Kuiken T (ed) Diagnosis of by-catch in cetaceans. Proc 2nd ECS Workshop on Cetacean Pathology. European Cetacean Society Newsletter 26 (Spec Issue), Saskatoon, p 35-37 
Baker JR, Martin AR (1992) Causes of mortality and parasites and incidental lesions in harbor porpoises (Phocoena phocoena) from British waters. Vet Rec 130: 554-558

Bancroft JD, Stevens A (eds) (1996) Theory and practice of histological techniques. Churchill Livingstone, New York, NY

Barrett T, Visser IK, Mamaev L, Goatley L, Van Bressem MF, Osterhaust AD (1993) Dolphin and porpoise morbilliviruses are genetically distinct from phocine distemper virus. Virology 193:1010-1012

Bogomolni AL, Pugliares KR, Sharp SM, Patchett K and others (2010) Mortality trends of stranded marine mammals on Cape Cod and southeastern Massachusetts, USA, 2000 to 2006. Dis Aquat Org 88:143-155

Bowater RO, Norton J, Johnson S, Hill B, O'Donoghue P, Prior H (2003) Toxoplasmosis in Indo-Pacific humpbacked dolphins (Sousa chinensis), from Queensland. Aust Vet J 81:627-632

Carrillo M, Ritter F (2010) Increasing numbers of ship strikes in the Canary Islands: proposals for immediate action to reduce risk of vessel-whale collisions. J Cetacean Res Manag 11(2):131-138

Carrillo M, Tejedor M (2006) Marine traffic and the conservation of sperm whale Physeter macrocephalus populations in Canary Islands. Cetacean stranded canarian net 1980-2004. Proc 20th Conf European Cetacean Society, Gdynia, p 115

Caswell JL, Williams KJ (2007) Respiratory system. In: Maxie MG (ed) Jubb, Kennedy and Palmer's pathology of domestic animals, 5th edn. Saunders Elsevier, Edinburgh, p 523-653

Cowan DF (1995) Amyloidosis in the bottlenose dolphin, Tursiops truncatus. Vet Pathol 32:311-314

Cowan DF, Tajima Y (2006) The thyroid gland in bottlenose dolphins (Tursiops truncatus) from the Texas coast of the Gulf of Mexico: normal structure and pathological changes. J Comp Pathol 135:217-225

Cowan DF, Walker WA, Brownell RL Jr (1986) Pathobiology of small cetaceans stranded along southern California beaches. In: Bryden MM, Harrison R (eds) Research on dolphins. Clarendon Press, Oxford, p 323-367

Cox TM, Read AJ, Barco S, Evans J and others (1998) Documenting the by-catch of harbour porpoises, Phocoena phocoena, in coastal gillnet fisheries from stranded carcasses. Fish Bull 96:727-734

Cox TM, Ragen TJ, Read AJ, Vos E and others (2006) Understanding the impacts of anthropogenic sound on beaked whales. J Cetacean Res Manag 7:177-187

Cruickshank JJ, Haines DM, Palmer NC, St Aubin DJ (1990) Cysts of a Toxoplasma-like organism in an Atlantic bottlenose dolphin. Can Vet J 31:213-215

Dailey MD (2001) Parasitic diseases. In: Dierauf LA, Gulland FMD (eds) CRC handbook of marine mammal medicine, 2nd edn. CRC Press, Boca Raton, FL, p 357-379

Dailey M, Stroud R (1978) Parasites and associated pathology observed in cetaceans stranded along the Oregon coast. J Wildl Dis 14:503-511

Dailey MD, Walker WA (1978) Parasitism as a factor (?) in single strandings of southern California cetaceans. J Parasitol 64:593-596

Degollada E, André M, Arbelo M, Fernandez A (2002) Incidence, pathology and involvement of Nasitrema species in odontocete strandings in the Canary Islands. Vet Rec 150:81-82

De Stephanis R, Urquiola E (2006) Collisions between ships and cetaceans in Spain. Paper SC/58/BC5 presented to the IWC Scientific Committee, June 2006, St Kitts and Nevis. IWC, Cambridge. Available at www.iwcoffice.co. uk/_documents/sci_com/SC58docs/SC-58-BC5.pdf

Dierauf LA, Gulland FMD (eds) (2001) CRC handbook of marine mammal medicine, 2nd edn. CRC Press, Boca Raton, FL

> Di Guardo G, Agrimi U, Morelli L, Cardeti G, Terracciano G, Kennedy S (1995) Post mortem investigations on cetaceans found stranded on the coasts of Italy between 1990 and 1993. Vet Rec 136:439-442

> Domingo M, Vilafranca M, Visa J, Prats N, Trudgett A, Visser I (1995) Evidence for chronic morbillivirus infection in the Mediterranean striped dolphin (Stenella coeruleoalba). Vet Microbiol 44:229-239

- Dubey JP, Zarnke R, Thomas NJ, Wong SK and others (2003) Toxoplasma gondii, Neospora caninum, Sarcocystis neurona, and Sarcocystis canis-like infections in marine mammals. Vet Parasitol 116:275-296

Dunn DG, Barco SG, Pabst DA, Mclellan WA (2002) Evidence for infanticide in bottlenose dolphins of the western North Atlantic. J Wildl Dis 38:505-510

Faris F, Hart K (1994). Seas of debris: a summary of the Third International Conference on Marine Debris. Publ No. UNC-SG-95-01, North Carolina Sea Grant College Program, Raleigh, NC

Fernández A, Edwards JF, Rodriguez F, Espinosa A and others (2005) Gas and fat embolic syndrome involving a mass stranding of beaked whales (family Ziphiidae) exposed to anthropogenic sonar signals. Vet Pathol 42:446-457

> Fernández A, Sierra E, Martín V, Méndez M and others (2012) Last 'atypical' beaked whales mass stranding in the Canary Islands (July, 2004). J Mar Sci Res Dev 2:107

Frantzis A (1998) Does acoustic testing strand whales? Nature 392:29

García del Moral R (ed) (1993) Laboratorio de anatomía patológica. McGraw-Hill/Interamericana, Madrid

Geraci JT, Lounsbury VJ (1993) Marine mammals ashore: a field guide for strandings. Texas A\&M University Sea Grant College Program, Galveston, TX

González L, Patterson IA, Reid RJ, Foster G and others (2002) Chronic meningoencephalitis associated with Brucella sp. infection in live-stranded striped dolphins (Stenella coeruleoalba). J Comp Pathol 126:147-152

Howard EB, Britt JO Jr, Matsumoto GK (1983). Parasitic diseases. In: Howard EB (ed) Pathobiology of marine mammal diseases. CRC Press, Boca Raton, FL, p 119-232

Hsu SM, Raine L, Fanger H (1981) Use of avidin-biotinperoxidase complex $(\mathrm{ABC})$ in immunoperoxidase techniques: a comparison between $\mathrm{ABC}$ and unlabeled antibody (PAP) procedures. J Histochem Cytochem 29: 577-580

Inskeep W, Gardiner CH, Harris RK, Dubey JP, Goldston RT (1990) Toxoplasmosis in Atlantic bottle-nosed dolphins (Tursiops truncatus). J Wildl Dis 26:377-382

Jaber JR, Pérez J, Arbelo M, Andrada M and others (2004) Hepatic lesions in cetaceans stranded in the Canary Islands. Vet Pathol 41:147-153

Jardine JE, Dubey JP (2002) Congenital toxoplasmosis in an Indo-Pacific bottlenose dolphin (Tursiops aduncus). J Parasitol 88:197-199

Jepson PD, Baker JR (1998) Bottlenosed dolphins (Tursiops truncatus) as a possible cause of acute traumatic injuries in porpoises (Phocoena phocoena). Vet Rec 143:614-615

Jepson PD, Bennett PM, Allchin CR, Law RJ and others (1999) Investigating potential associations between chronic exposure to polychlorinated biphenyls and infec- 
tious disease mortality in harbour porpoises from England and Wales. Sci Total Environ 243-244:339-348

Jepson PD, Arbelo M, Deaville R, Patterson IA and others (2003) Gas-bubble lesions in stranded cetaceans. Nature 425:575-576

Johnston DG, Ridgway SH (1969) Parasitism in some marine mammals. J Am Vet Med Assoc 155:1064-1072

Kirkwood JK, Bennett PM, Jepson PD, Kuiken T, Simpson VR, Baker JR (1997) Entanglement in fishing gear and other causes of death in cetaceans stranded on the coasts of England and Wales. Vet Rec 141:94-98

Kuiken T (1996) Review of the criteria for the diagnosis of by-catch in cetaceans. In: Kuiken T (ed) Diagnosis of bycatch in cetaceans. Proc 2nd ECS Workshop on Cetacean Pathology. European Cetacean Society Newsletter 26 (Spec Issue), Saskatoon, p 38-43

Kuiken T, García-Hartmann M (1991) Proc 1st ECS Workshop on Cetacean Pathology: Dissection techniques and tissue sampling. European Cetacean Society Newsletter 17 (Spec Issue), Saskatoon

Kuiken T, Simpson VR, Allchin CR, Bennett PM and others (1994) Mass mortality of common dolphins (Delphinus delphis) in south west England due to incidental capture in fishing gear. Vet Rec 134:81-89

Lair S, Beland P, De Guise S, Martineau D (1997) Adrenal hyperplastic and degenerative changes in beluga whales. J Wildl Dis 33:430-437

Laist DW (1996) Impacts of marine debris: Entanglement of marine life in marine debris including a comprehensive list of species with entanglement and ingestion records. In: Coe JM, Rogers DR (eds) Marine debris sources, impacts, and solutions. Springer-Verlag, New York, NY, p 99-139

Laist DW, Knowlton AR, Mead JG, Collet AS, Podesta M (2001) Collisions between ships and whales. Mar Mamm Sci 17:35-75

Lewis RJ, Berry K (1988) Brain lesions in a Pacific whitesided dolphin (Lagenorhynchus obliquidens). J Wildl Dis 24:577-581

Lunetta P, Modell JH (2005) Macroscopical, microscopical, and laboratory findings in drowning victims. a comprehensive review. Forensic Pathol Rev 3:3-77

Martín V, Servidio A, Tejedor M, Arbelo M and others (2009) Cetaceans and conservation in the Canary Islands. Proc 18th Biennial Conf Biology of Marine Mammals, Quebec, 12-16 October 2009, p 153

Migaki G, Van Dyke D, Hubbard RC (1971) Some histopathological lesions caused by helminths in marine mammals. J Wildl Dis 7:281-289

Migaki G, Sawa TR, Dubey JP (1990) Fatal disseminated toxoplasmosis in a spinner dolphin (Stenella longirostris). Vet Pathol 27:463-464

Mikaelian I, Boisclair J, Dubey JP, Kennedy S, Martineau D (2000) Toxoplasmosis in beluga whales (Delphinapterus leucas) from the St Lawrence estuary: two case reports and a serological survey. J Comp Pathol 122:73-76

Moore SE, Grebmeier JM, Davis JR (2003) Gray whale distribution relative to forage habitat in the northern Bering Sea: current conditions and retrospective summary. Can J Zool 81:734-742

Morimitsu T, Nagai T, Ide M, Ishii A, Koono M (1986) Parasitogenic octavus neuropathy as a cause of mass stranding of Odontoceti. J Parasitol 72:469-472

Morimitsu T, Kawano H, Torihara K, Kato E, Koono M (1992) Histopathology of eighth cranial nerve of mass stranded dolphins at Goto Islands, Japan. J Wildl Dis 28:656-658
Newman SJ, Smith SA (2006) Marine mammal neoplasia: a review. Vet Pathol 43:865-880

O'Hara KJ, Ludicello S (1994) A citizen's guide to plastics in the ocean: more than a litter problem. Center for Marine Conservation, Washington, DC

O'Shea TJ, Homer BL, Greiner EC, Layton AW (1991) Nasitrema sp. associated encephalitis in a striped dolphin (Stenella coeruleoalba) stranded in the Gulf of Mexico. J Wildl Dis 27:706-709

Parsons EC, Jefferson TA (2000) Post-mortem investigations on stranded dolphins and porpoises from Hong Kong waters. J Wildl Dis 36:342-356

Patterson IA, Reid RJ, Wilson B, Grellier K, Ross HM, Thompson PM (1998) Evidence for infanticide in bottlenose dolphins: an explanation for violent interactions with harbour porpoises? Proc R Soc Lond B Biol Sci 265:1167-1170

Perrin WF (1987) Stenella longirostris. Mamm Species 509:1-7

Prophet EB, Mills B, Arrington JB, Sobin LH (eds) (1992) Laboratory methods in histotechnology. Armed Forces Institute of Pathology/American Registry of Pathology, Washington, DC

Raga JA, Balbuena JA, Aznar J, Fernandez M (1997) The impact of parasites on marine mammals: a review. Parassitologia 39:293-296

Resendes AR, Juan-Salles C, Almeria S, Majo N, Domingo M, Dubey JP (2002) Hepatic sarcocystosis in a striped dolphin (Stenella coeruleoalba) from the Spanish Mediterranean coast. J Parasitol 88:206-209

Reynolds JE III, Rommel SA (1999) Biology of marine mammals. Smithsonian Institution Press, Washington, DC

> Ross HM, Wilson B (1996) Violent interactions between bottlenose dolphins and harbour porpoises. Proc R Soc Lond B Biol Sci 263:283-286

Schulman FY, Lipscomb TP (1999) Dermatitis with invasive ciliated protozoa in dolphins that died during the 1987-1988 Atlantic bottlenose dolphin morbilliviral epizootic. Vet Pathol 36:171-174

Spencer N, Santos MB, Pierce GJ (2000) Evaluation of the state of knowledge concerning by-catches of cetaceans. Final Report Tender No XIV/1999/01 Lot 7 (31/12/9931/10/00), European Commission, http://ec.europa.eu/ fisheries/documentation/studies/study_cetaceans/

Stroud RK, Roffe TJ (1979) Causes of death in marine mammals stranded along the Oregon coast. J Wildl Dis 15: 91-97

Tregenza NJC (1996) By-catch pathology as seen from the fishing boat. In: Kuiken $\mathrm{T}$ (ed) Diagnosis of by-catch in cetaceans. Proc 2nd ECS Workshop on Cetacean Pathology. European Cetacean Society Newsletter 26 (Spec Issue), Saskatoon, p 10-11

Tregenza NJC, Collet A (1998) Common dolphin Delphinus delphis bycatch in pelagic trawl and other fisheries in the Northeast Atlantic. Rep Int Whaling Comm 48: 453-459

Vandevanter DR, Warrener P, Bennett L, Schultz ER, Coulter S, Garber RL, Rose TM (1996) Detection and analysis of diverse herpesviral species by consensus primer PCR. J Clin Microbiol 34:1666-1671

Woodard JC, Zam SG, Caldwell DK, Caldwell MC (1969) Some parasitic diseases of dolphins. Pathol Vet 6: 257-272

Zam SG, Caldwell DK, Caldwell MC (1971) Some endoparasites from small odontocete cetaceans collected in Florida and Georgia. Cetology 2:1-11 